\title{
KAJIAN INSTRUMEN TES BIOLOGI KELAS X TERHADAP KETERAMPILAN BERPIKIR KRITIS TERINTEGRASI NILAI ISLAM
}

\author{
W. Wulandari ${ }^{*}$, Sulton Nawawi ${ }^{2}$, Tutik Fitri Wijayanti ${ }^{3}$,Suyud Abadi ${ }^{4}$ \\ 1, 2,3,4 Pendidikan Biologi FKIP, Universitas Muhammadiyah Palembang, Indonesia \\ Email: Ulanda93@gmail.coma
}

Received: November $11^{\text {th }}, 2019$. Accepted: November $29^{\text {th }}, 2019$. Published: December $29^{\text {th }}, 2019$

\begin{abstract}
The purpose of this study was determined the percentage numbers and indicators of critical thinking skills in Islamic values of instrument test to the X grade students of Islamic high schools. Method of the research was used descriptive-qualitative method. The research was used purposive sampling method, the test used final semester test questions through odd semester students of Islamic high school Seberang Ulu, Palembang. Technique of analysis the data was used percentage technique. The data obtained from biology final tests questions (UAS) of odd semester 2017/2018, (1) there were 5 indicators of critical thinking skills which was implemented the instrument tests with less category consisted of interpratation (7.02\%), analysis (1.89\%), evaluation (0\%), inference (5.52\%), explanation (11.37\%), and self-regulation (1.75\%), as well as the integration of Islamic values (0\%), (2) this indicator of critical thinking skills was categorized as lacking because there were two schools used test question which taken from text book and LKPD were commonly used in learning process.
\end{abstract}

Keywords: Biological Instrument Tests; Critical Thinking Skills; Integration of Islamic Values

\begin{abstract}
ABSTRAK
Penelitian ini untuk mengetahui jumlah persentase dan kajian perindikator keterampilan berpikir kritis terintegrasi nilai Islam pada instrumen tes biologi kelas X di SMA berbasis Islam. Metode penelitian menggunakan deskriptif kualitatif. Teknik pengambilan sampel menggunakan purposive sampling, sampel yang digunakan soal ulangan akhir semester (UAS) ganjil di SMA Berbasis Islam di Wilayah Seberang Ulu Kota Palembang. Teknik analisis data menggunakan teknik persentase. Hasil yang diperoleh dari analisis soal ulangan akhir semester (UAS) biologi semester ganjil tahun ajaran 2017/2018 adalah terdapat 5 indikator keterampilan berpikir kritis yang diterapkan pada instrumen soal dengan kategori kurang yang terdiri dari interpretasi $(7,02 \%)$, analisis $(1,89 \%)$, evaluasi $(0 \%)$, inferensi $(5,52 \%)$, penjelasan $(11,37 \%)$, dan pengaturan diri $(1,75 \%)$, serta Integrasi nilai Islam $(0 \%)$, dan indikator keterampilan berpikir kritis ini dikategorikan kurang karena terdapat 2 sekolah menggunakan soal yang mengambil dari buku paket dan LKPD yang biasa digunakan pada proses pembelajaran.
\end{abstract}

Kata Kunci: Instrumen Tes Biologi; Keterampilan Berpikir Kritis; Integrasi Nilai Islam

\section{PENDAHULUAN.}

Era globalisasi Bangsa Indonesia dihadapkan pada berbagai tantangan yang berskala global, seperti kebebasan, persaingan, pengetahuan (Mahsun 2013; Ginanjar 2017). Selain itu di era 4.0 saat ini menuntut perubahan yang luar biasa di dunia pendidikan (Hasanah dkk., t.t.; Pracihara 2018; Jatiyasa 2019) khususnya pada bidang teknologi . Melalui perkembangan teknologi dan informasi yang sangat cepat berkembang dan jika tidak 
diarahkan dengan baik kepada siswa maka akan dapat memberikan efek negatif, seperti krisisnya moral siswa (Manullang 2013; Oviyanti 2016). Strategis untuk menangani permasalahan dengan menanamkan nilai-nilai keimanan dan ketaqwaan (IMTAQ) atau memberdayakan nilai Islam pada proses pembelajaran (Maryamah 2016; Mukminah dan Wijaya 2015), karena siswa akan memiliki moral yang sesuai dengan nilai Islam yang telah diajarkan (Lili, 2014).

Keterampilan berpikir kritis dan integrasi nilai Islam penting diterapkan dalam pembelajaran di sekolah untuk mempersiapkan siswa yang memiliki atau dibekali kemampuan menghadapi atau memecahkan tantangan dan berbagai permasalahan (Endayani 2017; Mulyono 2018; Ekawati, Anggoro, dan Komarudin 2019). Asesment keterampilan berpikir penting diterapkan karena untuk mengetahui tigkat kemampuan berpikir kritis siswa sehingga guru dapat memutuskan apa yang akan diajarkan (Sumampouw 2011; Kurniati, Pujiastuti, dan Kurniasih 2017), motivasi bagi siswa untuk menjadi pemikir kritis yang lebih baik, memberikan informasi kepada guru tentang keberhasilan keterampilan berpikir kritis pada siswa (Insyasiska, Zubaidah, dan Susilo 2017), memberikan informasi untuk pembinaan serta untuk kebijakan sekolah yang dapat dipertanggung jawabkan terkait keterampilan berpikir kritis (Rositawati, t.t.).

Permasalahan yang terjadi sekarang juga yakni instrumen penilaian yang biasanya digunakan guru untuk menguji hasil belajar siswa berupa soal-soal yang cenderung lebih banyak menguji pada aspek ingatan saja (Septiana 2016; Budiman dan Jailani 2014), siswa harus mulai dilatih berpikir kritis baik dari tingkat interpretasi, analisis, evaluasi, inferensi, penjelasan, dan regulasi diri (Putra, Ariyanto, dan Prayitno 2016; Perdani, Santosa, dan Ramli, t.t.). Adapun penelitian berpikir kritis terintegrasi nilai-nilai keislaman belum pernah diteliti pada penelitian sebelumnya. Berdasarkan permasalahan tersebut tujuan penelitian ini adalah mengkaji instrumen tes biologi kelas $\mathrm{X}$ terhadap keterampilan berpikir kritis terintegrasi nilai Islam, karena dengan mengkaji dapat memberikan informasi tentang kualitas dari butir soal terhadap kemampuan berpikir kritis terintegrasi nilai Islam tersebut.

\section{METODE PENELITIAN}

Metode yang digunakan dalam penelitian ini adalah metode penelitian deskriptif kualitatif. Penelitian dilaksanakan pada bulan April 2018 di SMA berbasis Islam Wilayah Seberang Ulu Kota Palembang. Penentuan sampel menggunakan purposive sampling. 
Sampel pada penelitian ini adalah instrumen soal biologi di SMA berbasis Islam di wilayah Seberang Ulu Kota Palembang. Instrumen dalam penelitian menggunakan lembar wawancara sebagai data primer dan lembar observasi sebagai data sekunder.

Teknik pengumpulan data menggunakan (1) tahap dokumentasi dengan mengumpulkan soal UAS biologi semester ganjil kelas X-2 Wawancara dengan guru biologi kelas X-3 Observasi untuk menilai instrumen tes biologi berupa soal UAS semester ganjil kelas X yang berbasis keterampilan berpikir kritis terintegrasi nilai Islam. Data yang terkumpul diidentifikasi proporsinya berdasarkan kemampuan berpikir kritis dan integrasi nilai Islam. Hasil dari identifikasi soal yang telah memberdayakan keterampilan berpikir kritis dan integrasi nilai Islam persekolah dicari persentasenya, menggunakan rumus dibawah ini:

Persentase instrumen indikator keterampilan berpikir kritis:

$$
\text { Persentase }=\frac{\text { Jumlah Soal keterampilan berpikir kritis }}{\text { Jumlah Soal Objek Penelitian }} \times 100 \%
$$

Persentase Instrumen yang terintegrasi Islam:

$$
\text { Persentase }=\frac{\text { Jumlah Soal yang terintegrasi Islam }}{\text { Jumlah Soal Objek Penelitian }} \times 100 \%
$$

Setelah mendapatkan persentase persekolah, kemudian mencari persentase instrumen keterampilan berpikir kritis terintegrasi nilai Islam semua sekolah, hasil dari persentase instrumen kemampuan berpikir kritis terintegrasi nilai Islam semua sekolah tersebut dianalisis sesuai dengan kriteria yang telah ditentukan (Lihat pada Tabel 1). Teknik analisis data pada penelitian ini menggunakan Mc. Excel.

Tabel 1. Kategori Persentase Penilaian Instrumen Tes Indikator Keterampilan Berpikir kritis

\begin{tabular}{cc}
\hline Persentase & Kategori \\
\hline $68-100 \%$ & Baik \\
$34-67 \%$ & Cukup \\
$0-33 \%$ & Kurang \\
\hline
\end{tabular}

\section{HASIL PENELITIAN DAN PEMBAHASAN}

\section{Hasil Penelitian}

Berdasarkan hasil penelitian tentang kajian instrumen tes biologi kelas X terhadap keterampilan berpikir kritis terintegrasi nilai Islam di SMA Berbasis Islam Wilayah Seberang Ulu Kota Palembang diperoleh hasil yang tercantum pada Tabel 2. 
Tabel 2. Persentase Rata-rata Instrumen Tes Biologi Kelas X Terhadap Keterampilan Berpikir Kritis dan Integrasi Nilai Islam di SMA Berbasis Islam Wilayah Seberang Ulu Palembang

\begin{tabular}{lccc}
\hline Indikator Berpikir Kritis & $\begin{array}{c}\text { Jumlah } \\
(\mathbf{\%})\end{array}$ & Kategori & $\begin{array}{c}\text { Nilai Islam } \\
(\mathbf{\%})\end{array}$ \\
\hline Interpretasi & 7,02 & Kurang & $\mathbf{0}$ \\
Analisis & 1,89 & Kurang & \\
Evaluasi & 0 & Kurang & \\
Inferensi & 5,52 & Kurang & \\
Penjelasan & 11,37 & Kurang & \\
Pengaturan Diri & 1,75 & Kurang & \\
\hline & $\mathbf{2 7 , 5 5}$ & & $\mathbf{0}$ \\
\hline
\end{tabular}

Berdasarkan Tabel 2 diperoleh hasil yaitu 27,55\% soal yang telah memberdayakan keterampilan berpikir kritis pada SMA Berbasis Islam Wilayah Seberang Ulu, Palembang yang terdiri dari indikator yang lebih tinggi diberdayakan adalah 11,37\% soal yang memberdayakan indikator penjelasan, $7,02 \%$ indikator interpretasi, 5,52\% indikator inferensi, $1,89 \%$ indikator analisis dan $1,75 \%$ indikator pengaturan diri sedangkan indikator evaluasi belum diterapkan. Sedangkan integrasi nilai Islam 0\% artinya nilai Islam belum diberdayakan.

\section{Pembahasan}

Pada indikator interpretasi dikategorikan kurang karena beberapa guru belum terlalu memahami konsep indikator berpikir kritis. Indikator interpretasi adalah indikator berpikir kritis yang menuntut siswa untuk mengungkapkan sebuah arti sehingga guru sulit untuk membedakan soal yang termasuk indikator berpikir kritis atau termasuk kognitif. Berdasarkan hasil analisis soal UAS biologi semester ganjil tahun ajaran 2017/2018 lebih banyak soal yang meminta siswa untuk mengungkapkan suatu arti tetapi belum termasuk berpikir kritits atau hanya batas mengukur kognitif. Indikator interpretasi penting diterapkan dalam instrumen soal karena menuntut siswa untuk dapat memiliki kemampuan dalam mengkategorikan, mengklarifikasi dan mengungkapkan suatu arti.

Pada indikator analisis diperoleh 1,89\% dengan kategori kurang karena beberapa guru menyatakan bahwa soal UAS yang dibuat sesuai dengan kemampuan yang dimiliki siswa pada sekolah tersebut. Hal ini juga karena pada indikator analisis menuntut siswa untuk memiliki kemampuan dalam memilah, membedakan, mengelompokan, mengidentifikasi 
atau menghubungkan antara pernyataan, pertanyaan, konsep yang kemudian ditafsirkan maknanya.

Pada indikator evaluasi dikategorikan kurang karena indikator ini lebih mudah diterapkan pada proses pembelajaran terutama pada proses diskusi. Indikator evaluasi menuntut siswa untuk menilai kredibilitas klaim, ataupun menilai kualitas argumen dalam sebuah persoalan yang dicantumkan pada instrumen soal tersebut, serta dapat melatih kemampuan penalaran siswa dalam menilai. Pada indikator inferensi dikategorikan kurang karena menuntut siswa untuk memiliki kemampuan dalam membentuk suatu dugaan dan hipotesis, serta dapat mempertimbangkan informasi yang relevan, sehingga siswa dapat memperoleh bukti kueri, menduga dan menarik kesimpulan dari informasi yang diperoleh, hal ini berarti pada indikator inferensi lebih mudah diterapkan pada proses diskusi.

Indikator penjelasan dikategorikan kurang tetapi memiliki persentase yang lebih tinggi jika dibandingkan dengan persantase indikator analisis, evaluasi atau inferensi, karena soal UAS yang biasa digunakan adalah soal yang meminta siswa untuk menjelaskan suatu konsep, sedangkan untuk sub indikator penjelasan menggambarkan metode dan hasil, menjelaskan dan membenarkan prosedur dan membela dengan alasan-alasan belum diterapkan. Pada soal yang integrasi nilai Islam dikategorikan kurang. Hal ini sesuai dengan hasil wawancara bahwa beberapa guru menyatakan memang sulit dalam membuat soal yang mengintegrasikan nilai Islam, serta sudah ada mata pelajaran khusus yang mengukur nilai Islam pada siswa, dan ada juga guru menyatakan bahwa ia belum terpikir untuk menerapkan nilai Islam tersebut pada instrumen soal UAS biologi kelas $\mathrm{X}$ tahun ajaran 2017/2018, serta nilai Islam lebih mudah diberdayakan pada proses pembelajaran dibandingkan dengan memasukkan pada redaksi soal, dan tidak semua materi biologi kelas $\mathrm{X}$ ini dapat diintegrasikan nilai Islam tersebut. Beberapa guru juga mengambil soal untuk mengukur kemampuan siswa banyak yang mengambil dari buku paket biologi atau LKPD yang biasa mereka gunakan, sedangkan dalam buku IPA (Fisika, Kimia, Bumi, Biologi) yang diterbitkan oleh Depdiknas dan penerbit swasta jarang dan bahkan mungkin, tidak diintegrasikan dengan nilai-nilai agama (ayat-ayat Al-quran) yang dapat mengantarkan anak untuk mengagungkan ciptaanNya, hal ini karena buku tersebut diperuntukan semua konsumen yang berbeda-beda agama.

Berdasarkan hasil analisis soal UAS biologi semester ganjil kelas X tahun ajaran 2017/2018 tersebut juga didapatkan hasil bahwa pada soal tersebut lebih banyak 
memberdayakan keterampilan berpikir kritis pada indikator penjelasan dan interpretasi, dibandingkan dengan indikator analisis, penyimpulan, evaluasi dan pengaturan diri. Hal ini karena soal yang memberdayakan indikator analisis, penyimpulan, evaluasi dan pengaturan diri menuntut siswa untuk berpikir lebih luas dan kritis, mampu menilai, menyimpulkan dan dapat memonitor diri, sedangkan soal yang memberdayakan indikator interpretasi dan penjelasan hanya menuntut siswa untuk mengungkapkan sebuah arti dan penjelasan, sehingga soal buatan guru lebih banyak pada indikator interpretasi dan penjelasan, hal ini juga karena sesuai dengan kemampuan yang dimiliki siswa pada sekolah tersebut. Keterampilan berpikir kritis yang masi rendah adalah membuat kesimpulan dan menganalisis data, karena dua indikator ini adalah indikator yang tergolong berpikit kritis tingkat tinggi.

Guru menyatakan bahwa indikator evaluasi dan inferensi lebih mudah diterapkan pada proses pembelajaran, karena siswa dituntut untuk menilai dan menyimpulkan dibandingkan dengan memasukkan pada redaksi soal. Pada indikator penjelasan memiliki persentase lebih tinggi diterapkan guru pada instrumen soal UAS dibandingkan dengan indikator berpikir kritis yang memiliki tingkatan di bawah penjelasan seperti analisis, evaluasi dan inferensi, hal ini karena soal yang dibuat guru pada indikator penjelasan hanya mencakup sub indikator penjelasan konsep, pada pelajaran biologi tidak dapat terlepas dari pelajaran yang menuntut siswa untuk menjelaskan sebuah proses sehingga guru harus membuat soal yang menuntut siswa untuk menjelaskan, dan juga karena soal yang dianalisis hanya soal UAS biologi semester ganjil tahun ajaran 2017/2018, sedangkan ulangan harian tidak dapat dianalisis karena data soal tersebut tidak lengkap.

Pada beberapa sekolah juga menggunakan soal untuk menguji kemampuan siswa yang diambil dari buku-buku paket biologi yang mereka gunakan selama proses pembelajaran ataupun lembar kerja siswa (LKPD) yang digunakan juga dalam proses pembelajaran, sehingga soal yang diukur tersebut belum spesifik untuk mengukur keterampilan berpikir kritis pada siswa. Beberapa guru biologi yang terdapat pada SMA Berbasis Islam Wilayah Seberang Ulu Kota Palembang juga menyatakan bahwa untuk membuat soal yang mencantumkan indikator berpikir kritis seperti indikator evaluasi dan pengaturan diri tersebut sulit untuk dibuat terutama pada soal pilihan ganda, sehingga indikator tersebut hanya diberdayakan pada proses pembelajaran saja. Keterampilan berpikir kritis persentasenya lebih tinggi pada soal bentuk essay dibandingkan dengan soal 
pilihan ganda, hal ini karena pada soal pilihan ganda, guru lebih sulit meredaksi kalimat yang dapat mengukur keterampilan berpikir kritis dan pada soal essay guru lebih mudah membuat redaksi yang menuntut siswa berpikir kritis terutama pada indikator penjelasan, analisis, ataupun interpretasi.

Menurut Sari (2008) Soal berbentuk essay menuntut siswa untuk menjawab pertanyaan dalam bentuk menguraikan, menjelaskan, mendiskusikan, membandingkan, memberikan alasan, dan bentuk lain yang sejenisnya sesuai dengan tuntutan pertanyaan dengan menggunakan kata-kata dan bahasa sendiri sehingga dapat mengukur berpikir kritis. Hal ini diperkuat oleh (Zubaidah 2015) yang menyatakan soal berbentuk essay mendorong siswa untuk menunjukkan respon atau jawaban daripada hanya memillih jawaban dan mempunyai kemampuan untuk mengungkapkan alasan, menyusun, menganalisis, mensintesis dan mengevaluasi. Serta pada soal bentuk essay dapat menuntut siswa untuk berpikir dan bernalar sehingga dapat mudah megukur keterampilan berpikir kritis. Tetapi pada soal esai juga memiliki kelemahan yaitu kurang refresentatif dalam mewakili dari seluruh materi yang telah diajarkan karena butir soal esai hanya beberapa saja, sifatnya sangat subjektif (baik dalam menanyakan, membuat pertanyaan dan penskoran), memerlukan waktu yang cukup lama dalam mengoreksi serta dalam pemeriksaan soal lebih sukar. Sehingga meskipun tes essay dapat dengan mudah menerapkan keterampilan berpikir kritis, biasanya guru lebih memilih soal pilihan ganda, karena pada soal bentuk pilihan ganda lebih objektif dalam penskoran, dan juga dapat mengukur kemampuan siswa dari sederhana ke kompleks serta memerlukan waktu yang cepat dan singkat dalam pemeriksaannya.

Berdasarkan persentase instrumen soal terhadap keterampilan berpikir kritis pada SMA Berbasis Islam Wilayah Seberang Ulu Kota Palembang diperoleh hasil yaitu 27,55\% jumlah rata-rata soal yang mencantumkan keterampilan berpikir kitis yang terdiri dari indikator interpretasi, analisis, inferensi, penjelasan dan pengaturan diri dengan kategori perindikator kurang. Sesuai dengan hasil penelitian dari yang dilakukan oleh (Setiawan dan Harta 2014; Marwiyah, Kamid, dan Risnita 2015) yang menyatakan bahwa instrumen penilaian yang biasanya digunakan guru untuk menguji hasil belajar siswa berupa soal-soal tes yang biasanya dipakai di sekolah-sekolah kebanyakan hanya meliputi tugas-tugas yang harus dicari satu jawaban benar (berpikir konvergen), sehingga kemampuan berpikir kritis tidak terukur secara signifikan atau soal yang biasanya digunakan guru hanya menguji pada 
aspek ingatan saja. Guru biasanya hanya memberikan siswa latihan-latihan soal dengan soal yang biasa bukan yang berupa instrumen keterampilan berpikir kritis, sehingga siswa tidak terlatih untuk mengerjakan soal yang berpikir kritis (Kusumastuti, Rusilowati, dan Nugroho 2019; Pusparini, Sudrajat, dan Kaban 2019). Hal ini diperkuat lagi oleh (Warsiyo 2019; Setiadi 2016) mengungkapkan bahwa salah satu tantangan yang dihadapi dalam masa peralihan adalah keterbatasan kemampuan dan wawasan guru mengenai sistem penilaian dan salah satu hambatan penerapan pada kurikulum 2013 ini yaitu pada penyusunan penilaian. Soal-soal keterampilan berpikir kritis masih kurang mengarahkan dan melatih siswa untuk berpikir kritis (Rusyati dan Rustaman 2013; Pratiwi dan Rasmawan 2014). siswa harus mulai dilatih berpikir kritis baik dari tingkat interpretasi, analisis, evaluasi, inferensi, penjelasan dan regulasi diri (Ismi FirdanI 2015).

\section{KESIMPULAN}

Berdasarkan analisis di atas, maka dapat disimpulkan bahwa pada instrumen soal tes biologi ulangan akhir semester (UAS) ganjil kelas X tahun ajaran 2017/2018 di SMA Berbasis Islam Wilayah Seberang Ulu Kota Palembang diperoleh hasil persentase adalah terdapat 5 indikator keterampilan berpikir kritis yang diterapkan pada instrumen soal dengan kategori kurang yang terdiri dari interpretasi (7,02\%), analisis (1,89\%), evaluasi $(0 \%)$, inferensi $(5,52 \%)$, penjelasan $(11,37 \%)$, dan pengaturan diri $(1,75 \%)$, serta Integrasi nilai Islam $(0 \%)$, dan indikator keterampilan berpikir kritis ini dikategorikan kurang karena terdapat 2 sekolah menggunakan soal yang mengambil dari buku paket dan LKPD yang biasa digunakan pada proses pembelajaran.

Berdasarkan analisis data tersebut, maka penenlitian ini memiliki saran agar dapat melanjutkan penelitian yang lebih lanjut tentang kajian instrumen soal UAS ganjil maupun genap biologi kelas X pada jenjang sekolah lainnya atau mengembangkan instrumen soal UAS ganjil biologi kelas $\mathrm{X}$ terhadap keterampilan berpikir kritis terintegrasi nilai Islam.

\section{DAFTAR PUSTAKA}

Budiman, Agus, dan Jailani Jailani. 2014. "Pengembangan instrumen asesmen higher order thinking skill (HOTS) pada mata pelajaran matematika SMP kelas VIII semester 1." Jurnal Riset Pendidikan Matematika 1 (2): 139-51. 
Ekawati, Tia, Bambang Sri Anggoro, dan Komarudin Komarudin. 2019. "Pengembangan Modul Pembelajaran Matematika Pada Materi Statistika Terintegrasi Nilai-Nilai Keislaman." Aksioma: Jurnal Program Studi Pendidikan Matematika 8 (1): 184-92.

Endayani, Henni. 2017. "Visi Pembelajaran Ips Yang Powerful.” Ijtimaiyah 1 (2).

Ginanjar, Muhammad Hidayat. 2017. "Tantangan dan Peluang Lembaga Pendidikan Islam di Era Masyarakat Ekonomi Asean (MEA)." Edukasi Islami: Jurnal Pendidikan Islam 4 (08): 17.

HASANAH, Umi Nur, Andi Thahir, Komaruddin Komaruddin, dan Rahmahwaty Rahmahwaty. t.t. "MURDER Learning and Self Efficacy Models: Impact on Mathematical Reflective Thingking Ability." Journal for the Education of Gifted Young Scientists 7 (4): 1123-35.

Insyasiska, Dewi, Siti Zubaidah, dan Herawati Susilo. 2017. "Pengaruh project based learning terhadap motivasi belajar, kreativitas, kemampuan berpikir kritis, dan kemampuan kognitif siswa pada pembelajaran biologi." Jurnal Pendidikan Biologi 7 (1): 9-21.

Ismi Firdani, Alifia. 2015. "Pengembangan Lembar Kegiatan Siswa (Lks) Berorientasi Guided Discovery Untuk Melatihkan Keterampilan Berpikir Kritis Siswa Pada Materi Asam Basa Kelas Xi Sma (Development Of Student Activity Sheet Oriented Guided Discovery To Practice Student Critical Thinking Skill On Acid Base Material For Senior High School Grade Xi)." UNESA Journal of Chemical Education 4 (2).

Jatiyasa, I. Wayan. 2019. "Pembelajaran Bahasa Bali Di Era Revolusi Industri 4.0 (Peluang Dan Tantangannya).” Dalam Prosiding Seminar Nasional Dharma Acarya. Vol. 1.

Kurniati, Ida Wahyu, Emi Pujiastuti, dan Ary Woro Kurniasih. 2017. "Model pembelajaran discovery learning berbantuan smart sticker untuk meningkatkan disposisi matematik dan kemampuan berpikir kritis." Kreano, Jurnal Matematika KreatifInovatif 8 (2): 109-18.

Kusumastuti, Rahmi Puji, Ani Rusilowati, dan Sunyoto Eko Nugroho. 2019. "Pengaruh Keterampilan Berpikir Krtis Terhadap Literasi Sains Siswa." UPEJ Unnes Physics Education Journal 8 (3): 254-61.

Mahsun, Ali. 2013. "Pendidikan Islam dalam Arus Globalisasi: Sebuah Kajian Deskriptif Analitis.” Epistemé: Jurnal Pengembangan Ilmu Keislaman 8 (2): 259-78.

Manullang, Belferik. 2013. "Grand Desain Pendidikan Karakter Generasi Emas 2045." Jurnal Pendidikan Karakter, no. 1.

Marwiyah, Siti, Kamid Kamid, dan Risnita Risnita. 2015. "Pengembangan Instrumen Penilaian Keterampilan Berpikir Kreatif pada Mata Pelajaran IPA Terpadu Materi 
Atom, Ion, dan Molekul SMP Islam Al Falah.” Edu-Sains: Jurnal Pendidikan Matematika dan Ilmu Pengetahuan Alam Universitas Jember 4 (1).

Maryamah, Eva. 2016. "Pengembangan Budaya Sekolah." Tarbawi: Jurnal Keilmuan Manajemen Pendidikan 2 (02): 86-96.

Mukminah, Mukminah, dan Hadi Wijaya. 2015. "Problematika Pengintegrasian Nilai-Nilai Islam Dalam Pembelajaran Ilmu Pengetahuan Alam (IPA) Di Tingkat Sekolah Dasar." Jurnal Ilmiah Mandala Education (JIME) 1 (2): 277-89.

Mulyono, Mulyono. 2018. "Keefektifan Metode Problem Based Learning dalam Pembelajaran Fiqih di Perguruan Tinggi." CENDEKIA: Jurnal Studi Keislaman 2 (2).

Oviyanti, Fitri. 2016. "Tantangan Pengembangan Pendidikan Keguruan di Era Global." Nadwa 7 (2): 267-82.

Perdani, Wahyu Setiya Roning, Slamet Santosa, dan Murni Ramli. t.t. "Peningkatan Kemampuan Berpikir Kritis Siswa SMA dengan Model Inkuiri pada Materi Sistem Indera." BIO-PEDAGOGI 8 (1): 52-55.

Pracihara, Biwara Sakti. 2018. "SMK Seni Dalam Konstelasi Revolusi Industri 4.0." Dalam Seminar Nasional Seni dan Desain 2018, 1-5. State University of Surabaya.

Pratiwi, Fitri Apriani, dan Rahmat Rasmawan. 2014. "Pengaruh Penggunaan Model Discovery Learning Dengan Pendekatan Saintifik Terhadap Keterampilan Berpikir Kritis Siswa SMA.” Jurnal Pendidikan dan Pembelajaran 3 (7).

Pusparini, Defi Intan, Ajat Sudrajat, dan Sehati Kaban. 2019. "Meningkatkan Kemampuan Berpikir Kritis Dalam Pembelajaran Ilmu Pengetahuan Sosial Dengan Model Problem Based Learning Kelas Iv.” Dinamika IPS Sekolah Dasar 1 (1): 1-14.

Putra, Bartolomeus Kristi Brahmantia, Joko Ariyanto, dan Baskoro Adi Prayitno. 2016. "Penerapan Model Konstruktivis-Metakognitif pada Materi Sistem Koordinasi untuk Meningkatkan Berpikir Kritis Siswa Kelas XI MIPA SMA.” Dalam Proceeding Biology Education Conference: Biology, Science, Enviromental, and Learning, 13:169-77.

Rositawati, Dwi Nugraheni. t.t. "KAJIAN BERPIKIR KRITIS PADA METODE INKUIRI.” Dalam Prosiding SNFA (Seminar Nasional Fisika dan Aplikasinya), $3: 74-84$.

Rusyati, Lilit, dan Nuryani Rustaman. 2013. "Pengembangan Soal Pilihan Ganda Berpikir Kritis Inch Dan Profil Pencapaiannya Di Sma Negeri Kota Bandung Pada Tema Penyakit Manusia.” Jurnal Pengajaran MIPA 18 (1): 124-34. 
Septiana, Nurul. 2016. "Analisis Butir Soal Ulangan Akhir Semester (UAS) Biologi Tahun Pelajaran 2015/2016 Kelas X dan XI pada Man Sampit." Edu Sains: Jurnal Pendidikan Sains \& Matematika 4 (2).

Setiadi, Hari. 2016. "Pelaksanaan penilaian pada Kurikulum 2013." Jurnal Penelitian dan Evaluasi Pendidikan 20 (2): 166-78.

Setiawan, Raden Heri, dan Idris Harta. 2014. "Pengaruh pendekatan open-ended dan pendekatan kontekstual terhadap kemampuan pemecahan masalah dan sikap siswa terhadap matematika." Jurnal Riset Pendidikan Matematika 1 (2): 241-57.

Sumampouw, Herry Maurits. 2011. "Keterampilan Metakognitif dan Berpikir Tingkat Tinggi dalam Pembelajaran Genetika (Artikulasi Konsep dan Verifikasi Empiris).” Bioedukasi 4 (2).

Warsiyo, Warsiyo. 2019. “Aplikasi Sistem Penilaian Pencapaian Kompetensi siswa Untuk Guru Mata Pelajaran Dan Wali Kelas Di MTs Negeri 5 Sleman.” Dalam Seri Prosiding Seminar Nasional Dinamika Informatika. Vol. 2.

Zubaidah, Siti. 2015. "Asesmen Berpikir Kritis Terintegrasi Tes Essay.” Dalam Prosiding Symposium on Biology Education (Symbion), 200-209. 
